\title{
Research Article \\ Effect of Condenser Fouling on Performance of Vapor Compression Refrigeration System
}

\author{
Naveen Solanki, ${ }^{1}$ Akhilesh Arora, ${ }^{2}$ and S. C. Kaushik ${ }^{3}$ \\ ${ }^{1}$ Department of Mechanical and Automation Engineering, Maharaja Agrasen Institute of Technology, Sector 22, \\ Rohini, Delhi 110086, India \\ ${ }^{2}$ Department of Mechanical Engineering, Delhi Technological University, Delhi 110042, India \\ ${ }^{3}$ Department of Energy Studies, IITD, Hauz Khas, New Delhi 110016, India \\ Correspondence should be addressed to Akhilesh Arora; akhilesharora@dce.ac.in
}

Received 15 July 2015; Accepted 30 August 2015

Academic Editor: Shripad T. Revankar

Copyright (c) 2015 Naveen Solanki et al. This is an open access article distributed under the Creative Commons Attribution License, which permits unrestricted use, distribution, and reproduction in any medium, provided the original work is properly cited.

Effect of condenser fouling is evaluated on the performance of a vapour compression system with refrigerants HFO1234yf and HFO1234ze as an alternative to HFC134a. The condenser coolant temperature has been varied between 35 and $40^{\circ} \mathrm{C}$ to evaluate the effect of fouling at different condenser temperatures. A simulation model is developed in EES for computing the results. The results have been computed by varying condenser conductance. The same has been validated with literature available before calculating the results. It is observed that the condenser fouling has larger effect on compressor power $\left(W_{\mathrm{cp}} \%\right)$ as it increases up to 9.12 for R1234yf and 7.41 for R1234ze, whereas for R134a its value increases up to 7.38. The cooling capacity ( $\left.Q_{\text {evap }} \%\right)$ decreases up to 13.25 for R1234yf and 8.62 for R1234ze, whereas for R134a its value decreases up to 8.76. The maximum percentage of decrease in value of COP is up to 19.29 for R1234yf and 14.47 for R1234ze, whereas for R134a its value decreases up to 14.49. The second-law efficiency is also observed to decrease with decrease in the condenser conductance. The performance of HFO1234ze is found to be better under fouled conditions in comparison to R134a and R1234yf.

\section{Introduction}

The most commonly used refrigerants in recent past were R11, R12, and R22 which because of their high ODP have been either phased out or under consideration for the same. After the revelation of the harmful effects of CFC and $\mathrm{HCFC}$ refrigerants on the ozone layer, search to find alternative working fluids gained more interest in the recent few years. The HFC134a was found to be a suitable candidate for replacing R12 and is being successfully used to date in small equipment like domestic refrigerators and water coolers and in mobile air-conditioning. HFC134a has very high GWP which is a matter of environmental concern. Calm [1] reviewed the progression of refrigerants from early uses to the present and addressed future direction by identifying pending policy and regulation that may impact the next generation of refrigerants significantly. Presently the fourth-generation refrigerants are in progress and these have low GWP such as HFO1234yf and HFO1234ze.
Karber et al. [2] examined refrigerants HFO1234yf and HFO1234ze as drop-in replacements for R134a in domestic refrigerators. Their results showed that HFO1234yf consumes $2.7 \%$ and $1.3 \%$ higher energy than HFC134a in baseline refrigerator and refrigerator based on advanced technology respectively; whereas HFO1234ze showed $16 \%$ and $5.4 \%$ lower energy consumption than HFC134a.

Ansari et al. [3] carried out the exergy analysis of HFO1234yf and HFO1234ze as a replacement to HFC134a. Their results indicate that HFO1234yf and HFO1234ze can be good replacement for HFC134a.

McLinden et al. [4] measured the thermodynamic properties of HFO1234ze and compared the experimental data with calculated data to establish the accuracy of EOS.

Reasor et al. [5] identified that refrigerant R1234yf has a low GWP of 4 in comparison to 1430 for R134a and has similar thermodynamic properties to those of HFC134a which make R1234yf a worthy choice for future automotive refrigerants. 
A computer simulation was also conducted for feasibility of using R1234yf as a replacement for R134a and R410A.

Jarall [6] calculated and compared the theoretical cycle data and heat transfer of HFO1234yf with HFC134a in a refrigeration plant using a hermetic rotary compressor of $550 \mathrm{~W}$ nominal output power. The experimental results showed that HFO1234yf gives less refrigerating capacity, COP, and compressor efficiency by $3.4-13.7 \%, 0.35-11.88 \%$, and $0-$ $6.3 \%$ in comparison to HFC134a. Yamada et al. [7] examined that HFO1234yf is a potential working fluid of organic rankine cycle for low to medium temperature. HFO1234yf was found to offer almost similar thermal efficiency as that of HFC134a for all organic rankine cycle models. Thus HFO1234yf can be replaced by HFC134a.

Lee and Jung [8] examined the performance of HFO1234yf and HFC134a in a mobile air-conditioning bench tester under summer and winter conditioning. The results showed that the COP, capacity, and compressor discharge temperature for HFO1234yf are $2.7 \%, 4.0 \%$, and $6.5^{\circ} \mathrm{C}$ lower than those of HFC134a and the amount of charge required for HFO1234yf reduced up to $10 \%$.

According to this literature survey HFOs are future refrigerant for use in vapour compression systems. However the performance evaluation of these alternate refrigerants is necessary before these are commercially used in the system. The commercial usage demands the performance evaluation not only under ideal conditions but also under actual working conditions. The performance under actual conditions also depends on the fouling of heat exchangers (condensers) during operation of system. The material deposits on the surfaces of the heat exchanger tubes (fouling) add more thermal resistance to heat transfer which significantly affects the heat exchanger performance thereby affecting the system performance. A few notable studies on the effect of fouling on a vapor compression system have been reported in the next paragraph.

Qureshi and Zubair [9] discussed the effect of fouling on the performance of VCRS on the basis of first and second law and calculated the results for a particular set of data assuming condenser coolant temperature of $40^{\circ} \mathrm{C}$ and inlet air temperature to evaporator as $0^{\circ} \mathrm{C}$ and isentropic efficiency of compressor is assumed as 65\%. Their results substantiate that R134a performs better among R134a, R410A, and R407C and similarly R717 performs better among R717, R404, and R290. The results of Qureshi and Zubair [9] are of limited use because the analysis has been performed for a condenser coolant temperature equal to $40^{\circ} \mathrm{C}$. The condenser temperature in a real system depends on ambient conditions which keep on varying throughout the day.

Qureshi and Zubair [10] examined that energy can be saved by incorporating a mechanical subcooling to existing refrigeration and air-conditioning system under fouled condition. The results have been presented for HFC134a, R410A, R407C, R717, R404, and R290.

Qureshi and Zubair [11] examined experimentally the effect of condenser fouling on performance characteristics of a simple vapour compression system using HCFC22. The effect of condenser fouling was examined by blocking a part of air flow passage in condenser and its effect was studied on condenser pressure, superheat temperature at compressor exit, compressor power consumption, and COP. Their results indicate a logarithmic behavioral change in above-mentioned parameters. In above-mentioned studies on fouling, the analysis has been performed for refrigerants which have high GWP, that is, R134a, R407C, R410A, and R404A, besides low GWP refrigerants HC290 and R717. The high GWP refrigerants are to be replaced by low GWP refrigerants such as HFO1234yf and HFO1234ze.

Presently the system performance is being computed using two approaches, namely, (i) on the basis of first law of thermodynamics and (ii) on the basis of combined first and second law of thermodynamics. The analysis of systems based on combined first and second laws of thermodynamics is a better approach. Many researchers are focusing on the analysis of thermal systems based on this approach. The analysis based on second approach is also known as exergy analysis. The concept of exergy analysis as compared to energy analysis is more useful as it helps to quantify the irreversibility occurring in the system components. The effect of variation in condenser conductance's and condenser coolant inlet temperatures has been examined on the performance of the system. The parameters computed are percentage of change in COP, cooling capacity, compressor work, and effectiveness. The second-law efficiency is also computed. The following paragraph highlights how the fouling may occur in actual conditions.

Refrigerant R134a is commonly used refrigerant in VCRS, especially in mobile air-conditioning (Lee and Jung [8]) system such as cars; however its GWP is 1430 . HFO1234yf and HFO1234ze have very low GWP value of 4 and are used as alternatives to R134a in mobile air-conditioning system. In the present study, the focus area is mobile air-conditioning and the effect of condenser fouling on system performance. The condenser fouling in mobile air-conditioning system is a very common phenomenon over a period of time which results in drop of performance. The fouling may happen due to accumulation of dust and dirt and scale formation (i.e., fluid impurities, corrosion, chemical reactions, encrustation, slagging, and sludge formation) on condenser tubes of airconditioning system. The scale deposition offers an additional resistance to heat flow between the fluids and when resistance becomes double the condenser conductance drops to $50 \%$ in actual situations. Such situation of drop in conductance may occur due to nonservicing of the mobile air-conditioning system over a long period of usage of vehicle.

\section{System and Model Descriptions}

A simple vapour compression refrigeration cycle consists of the following equipment: (i) compressor, (ii) condenser, (iii) expansion valve, and (iv) evaporator, as shown in Figure 1.

Figure 2 shows a simple vapour compression refrigeration cycle on $T-S$ diagram for different compression processes. The cycle works between temperatures $T_{1}$ and $T_{2}$ representing the condenser and evaporator temperatures, respectively:

(i) Process 4-5s: isentropic compression of the vapor from state 4 to state $5 \mathrm{~s}$. However, the compression 


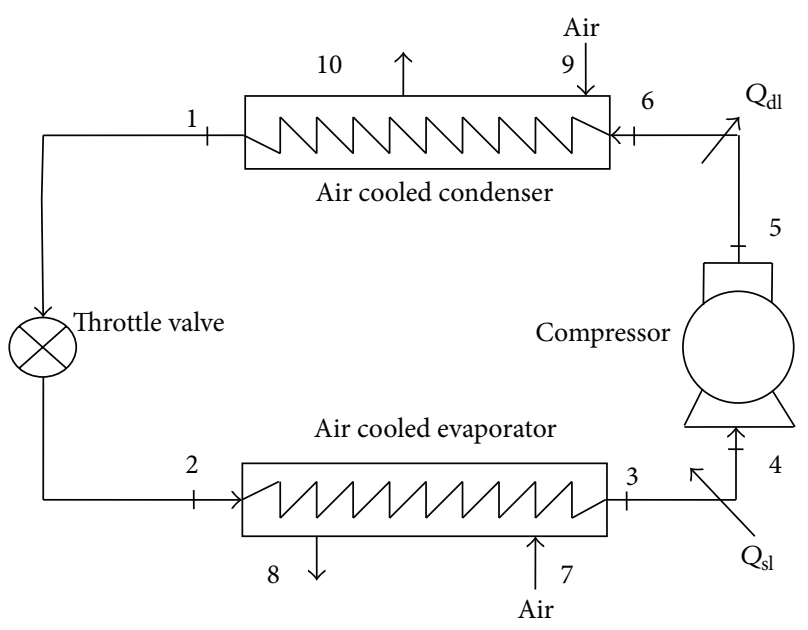

FIGURE 1: Schematic diagram of a simple VCRS.

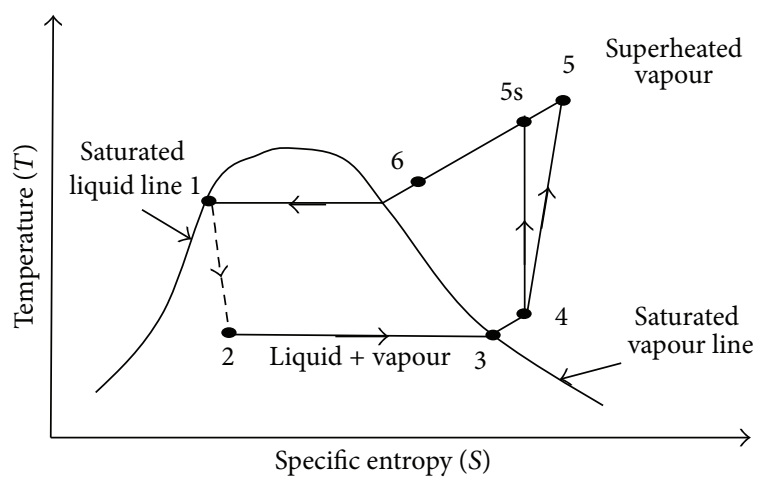

FIgURE 2: Temperature-entropy diagram of VCRC.

is never isentropic and hence in actual compression process (4-5) the exit state from the compressor is 5 .

(ii) Process 5-6: heat rejection at constant pressure to the surroundings from the discharge line.

(iii) Process 6-1: heat rejection in condenser at constant pressure.

(iv) Process 1-2: an irreversible adiabatic expansion of vapor through the expansion valve or throttling device. The pressure and temperature of the liquid are reduced. The process is accompanied by partial evaporation of some liquid. The process is shown by dotted line because it is irreversible.

(v) Process 2-3: heat absorption in evaporator at constant pressure. In the final state 3 the refrigerant is in the dry saturated state at the exit from the evaporator.

(vi) Process 3-4: the temperature at the exit is lower than the ambient temperature; hence heat is transferred from surroundings to the refrigerant in the suction line at constant pressure.
Considering the steady-state cyclic operation and applying the first law of thermodynamics to the system as shown in Figure 2, (1) can be obtained. Consider

$$
\dot{Q}_{\text {cond }}+\dot{Q}_{\text {loss,cond }}-\left(\dot{Q}_{\text {evap }}+\dot{Q}_{\text {loss,evap }}\right)-\dot{W}_{\text {cp }}=0 .
$$

The heat transfer rate in the evaporator is given by

$$
\dot{Q}_{\text {evap }}=\dot{m}_{\text {ref }}\left(h_{3}-h_{2}\right) \text {. }
$$

In terms of effectiveness $(\epsilon)$, minimum heat capacity $\left(C_{\min }\right)$ and temperature difference $\dot{Q}_{\text {evap }}$ can be written as

$$
\dot{Q}_{\text {evap }}=\left(\epsilon C_{\text {min }}\right)_{\text {evap }}\left(T_{7}-T_{2}\right) \text {, }
$$

where $T_{2}$ is the temperature of refrigerant entering to evaporator and $T_{7}$ is the outside air temperature entering to evaporator. by

Similarly, the heat transfer rate in the condenser is given

$$
\dot{Q}_{\text {cond }}=\dot{m}_{\text {ref }}\left(h_{6}-h_{1}\right)=\left(\epsilon C_{\text {min }}\right)_{\text {cond }}\left(T_{1}-T_{9}\right),
$$

where $T_{1}$ is the temperature of saturated liquid refrigerant leaving the condenser and $T_{9}$ is the outside air temperature entering the condenser for cooling the refrigerant in the condenser.

The power required by the compressor is presented in terms of isentropic efficiency of the compressor, given by

$$
\dot{W}_{\mathrm{cp}}=\dot{m}_{\mathrm{ref}}\left(h_{5}-h_{4}\right)=\frac{\dot{m}_{\mathrm{ref}}\left(h_{5 \mathrm{~s}}-h_{4}\right)}{\eta_{\mathrm{cp}, \mathrm{ssn}}},
$$

where point 5 shows the actual state of refrigerant vapour at the exit from compressor.

Work input to the compressor can also be expressed using steady flow energy equation as follows:

$$
\dot{Q}_{\mathrm{cp}}-\dot{W}_{\mathrm{cp}}=\dot{m}_{\mathrm{ref}}\left(h_{5}-h_{4}\right),
$$

where $\dot{Q}_{c p}$ is the heat transfer from the compressor to the surroundings.

The heat leaking into the suction line is represented by

$$
\dot{Q}_{\mathrm{sl}}=\dot{m}_{\mathrm{ref}}\left(h_{4}-h_{3}\right) \text {. }
$$

The heat leakage from the discharge line to surroundings can be expressed as

$$
\dot{Q}_{\mathrm{dL}}=\dot{m}_{\mathrm{ref}}\left(h_{6}-h_{5}\right) .
$$

The COP is the ratio of refrigerating effect to compressor power; that is,

$$
\mathrm{COP}=\frac{Q_{\text {evap }}}{W_{\mathrm{cp}}} .
$$

The first-law efficiency alone is not a realistic measure of performance of engineering device. To overcome this deficiency, we define second-law efficiency $\left(\eta_{\mathrm{II}}\right)$ of a refrigeration system 
TABle 1: Model, specification and equations of components considered in the analysis (Qureshi and Zubair [9], Stoecker and Jones [13]).

\begin{tabular}{llll}
\hline Component & Model and specification & Equation & Remarks \\
\hline Compressor & H62SP-22E $(1750 \mathrm{rpm})$ & $W_{\mathrm{cp}}=\frac{m_{\mathrm{ref}}\left(h_{5 \mathrm{~s}}-h_{4}\right)}{\eta_{\mathrm{cp}, \text { isn }}}$ & Hermetic reciprocating \\
\hline Condenser & Model number 36 & $Q_{\text {cond }}=F *\left(T_{1}-T_{\text {in, cond }}\right)$ & $\begin{array}{l}F=\left(\epsilon C_{\text {min }}\right)_{\text {cond }}=9.39 \mathrm{~kW} / \mathrm{K} \\
F=\text { capacity per unit temperature difference }(\mathrm{kW} / \mathrm{K})\end{array}$ \\
\hline Evaporator & CH660B & $Q_{\text {evap }}=G *\left(T_{\text {in,evap }}-T_{2}\right)$ & $\begin{array}{l}G=\left(\epsilon C_{\text {min }}\right)_{\text {evap }}=6\left[1+0.046\left(T_{\text {in,evap }}-T_{2}\right)\right] \\
G=\text { proportionality factor }(\mathrm{kW} / \mathrm{K})\end{array}$ \\
\hline
\end{tabular}

TABLE 2: Comparison of performance data from Stoecker and Jones [13] and current model for refrigerant R22.

\begin{tabular}{lcccccccccccc}
\hline $\begin{array}{l}T_{\text {in,evap }} \\
\left({ }^{\circ} \mathrm{C}\right)\end{array}$ & $\begin{array}{c}Q^{*} \text { cond } \\
(\mathrm{kW})\end{array}$ & $\begin{array}{c}Q_{\text {cond,mod }} \\
(\mathrm{kW})\end{array}$ & $\begin{array}{c}\text { Error } \\
(\%)\end{array}$ & $\begin{array}{c}W^{*}{ }_{\mathrm{cp}} \\
(\mathrm{kW})\end{array}$ & $\begin{array}{c}W_{\text {cp,mod }} \\
(\mathrm{kW})\end{array}$ & $\begin{array}{c}\text { Error } \\
(\%)\end{array}$ & $\begin{array}{c}T^{*}{ }_{1} \\
\left({ }^{\circ} \mathrm{C}\right)\end{array}$ & $\begin{array}{c}T_{1, \bmod } \\
\left({ }^{\circ} \mathrm{C}\right)\end{array}$ & $\begin{array}{c}\text { Error } \\
(\%)\end{array}$ & $\begin{array}{c}\mathrm{COP}^{*} \\
(\mathrm{~kW})\end{array}$ & $\begin{array}{c}\mathrm{COP}_{\text {mod }} \\
(\mathrm{kW})\end{array}$ & $\begin{array}{c}\text { Error } \\
(\%)\end{array}$ \\
\hline $\mathbf{0}$ & 82.16 & $\mathbf{8 2 . 4 0}$ & $\mathbf{0 . 2 9}$ & 24.92 & $\mathbf{2 5 . 1 9}$ & $\mathbf{1 . 0 7}$ & 48.75 & $\mathbf{4 8 . 7 7}$ & $\mathbf{0 . 0 4}$ & 2.30 & $\mathbf{2 . 2 7}$ & $\mathbf{- 1 . 3 2}$ \\
$\mathbf{1 5}$ & 122.0 & $\mathbf{1 2 2 . 9 3}$ & $\mathbf{0 . 5 7}$ & 31.45 & $\mathbf{3 2 . 3 7}$ & $\mathbf{2 . 8 4}$ & 52.99 & $\mathbf{5 3 . 0 9}$ & $\mathbf{0 . 1 8}$ & 2.88 & $\mathbf{2 . 8 0}$ & $\mathbf{- 2 . 7 7}$ \\
\hline
\end{tabular}

${ }^{*}$ From the performance data of stoecker and jones [13].

which is the ratio of the actual coefficient of performance (COP) to the maximum possible coefficient of performance $\left(\mathrm{COP}_{\text {rev }}\right)$ under the same operating conditions:

$$
\eta_{\mathrm{II}}=\frac{\mathrm{COP}}{\mathrm{COP}_{\text {rev }}}=\frac{\eta_{\mathrm{I}}}{\eta_{\mathrm{th}, \mathrm{rev}}},
$$

where

$$
\mathrm{COP}_{\text {rev }}=\frac{T_{7}}{T_{9}-T_{7}}
$$

The effectiveness of a heat exchanger is defined using

$$
\epsilon=\frac{\text { Actual heat transfer }}{\text { maximum possible heat transfer }}
$$

The effectiveness of evaporator and condenser is given by

$$
\begin{gathered}
\epsilon_{\text {evap }}=\frac{T_{7}-T_{8}}{T_{7}-T_{2}}, \\
\epsilon_{\text {cond }}=\frac{T_{10}-T_{9}}{T_{6}-T_{9}} .
\end{gathered}
$$

Incropera et al. [12] derived the expression for relation between effectiveness, heat capacity, and overall conductance (UA) which is expressed as

$$
\mathrm{UA}=C_{\min } * \ln \left(\frac{1}{1-\epsilon}\right) .
$$

The fouling on air side of a heat exchanger is the reason for reduction of UA. The percentage reduction in conductance is represented using

$$
\mathrm{UA} \%=\left(1-\frac{\mathrm{UA}}{\mathrm{UA}_{\mathrm{cl}}}\right) * 100 .
$$

In this study, a programme is developed using Engineering Equation Solver (EES) for the simulation of system performance using set of (1) to (15) in which percentage of decrease in the conductance value due to fouling has been varied from $0 \%$ to $50 \%$ in condenser. The flow chart showing the simulation procedure of the EES program, developed for computation of results, is given in Figure 3. The properties (of refrigerants R134a, R1234yf, and R1234ze) such as enthalpy, entropy, pressures, and temperatures are given in the form of inbuilt functions in EES and are called in the EES program for calculation of parameters, namely, cooling effect, compressor work, and heat rejected in condenser. The clean conditions refer to no fouling; that is, percentage of reduction in conductance is $0 \%$. Heat leakages in the suction line and discharge line and pressure drops in the heat exchangers are considered negligible in all the calculations and hence not taken into account.

2.1. Model Validation. This section presents the model validation of the EES program used for the evaluation of vapour compression system. The data used for the validation purpose have been obtained from Stoecker and Jones [13]. The details of equations with model are given in Table 1.

The comparison of performance data from Stoecker and Jones [13] and current model for refrigerant R22 (refer to Table 2$)$ depicts that all relevant quantities $\left(Q_{\text {cond }}, W_{\mathrm{cp}}\right.$, and COP along with the temperature of refrigerant at condenser outlet $\left(T_{1}\right)$ and temperature of air entering the evaporator $\left(T_{7}\right)$ ) can be prognosticated by the property based model correctly and the maximum error was found to be 2.84 .

(i) Table 3 gives the comparison of data from Qureshi and Zubair [9] with current model for refrigerant R134a. It is observed that error (\%) in COP is less than $1 \%$.

\section{Results and Discussion}

The thermodynamic model given above is used to evaluate the performance of vapor compression system. The performance is evaluated with three refrigerants (R134a, R1234yf, and R1234ze). 


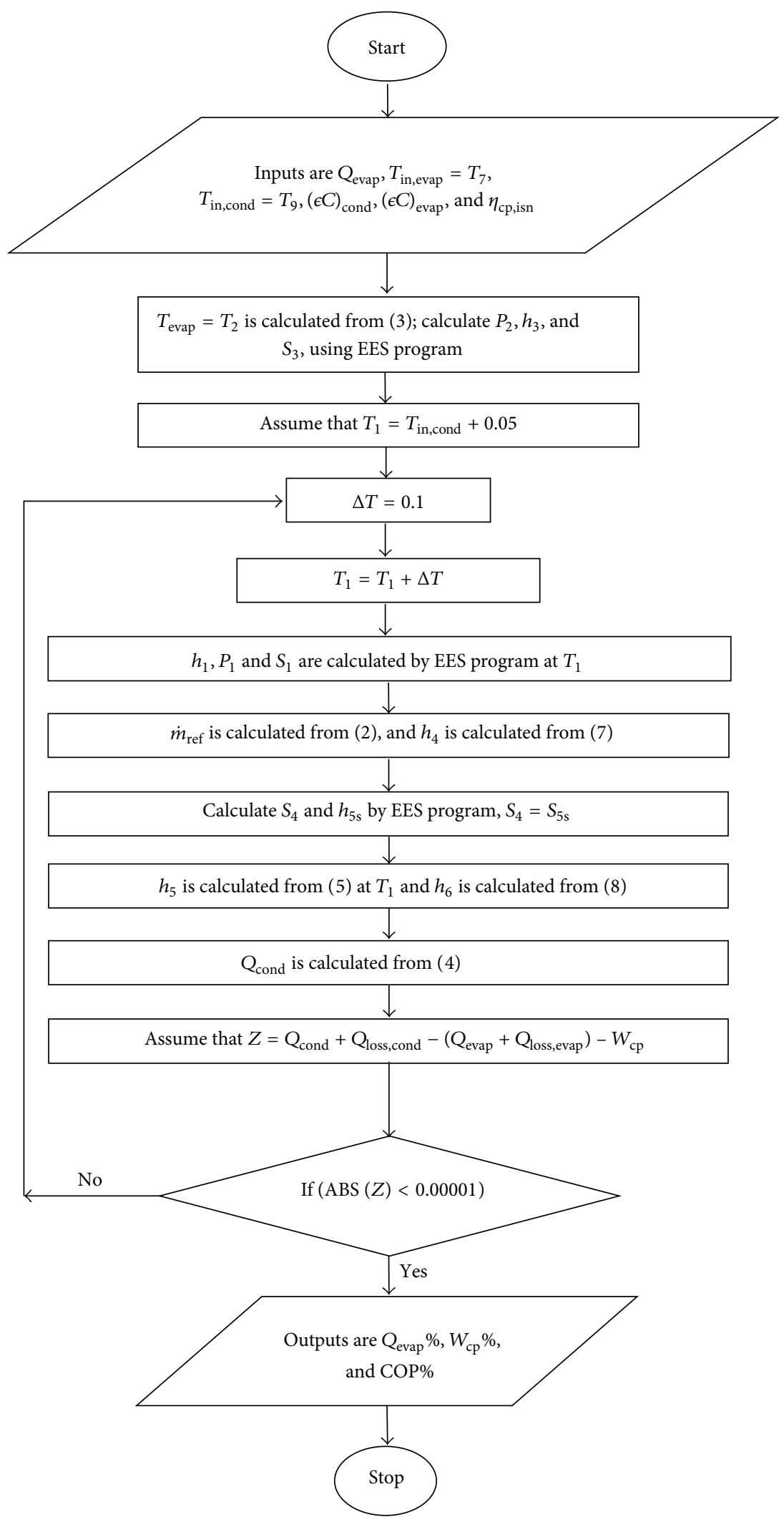

FIGURE 3: A flow chart for thermodynamic model of simple VCRS. 
TABLE 3: Comparison of present model with work of Qureshi and Zubair [9] for condenser fouling of refrigerant $\mathrm{R} 134 \mathrm{a}\left(\mathrm{Te}=0^{\circ} \mathrm{C}\right)$.

\begin{tabular}{|c|c|c|c|c|c|c|c|}
\hline \multirow{2}{*}{$\begin{array}{l}\text { Reduction in } \\
\mathrm{UA}_{\text {cond }}(\%)\end{array}$} & \multicolumn{2}{|c|}{ Change in $Q_{\text {evap }}(\%)$} & \multicolumn{2}{|c|}{ Change in $W_{\mathrm{cp}}(\%)$} & \multicolumn{2}{|c|}{ Change in COP (\%) } & \multirow{2}{*}{$\begin{array}{c}\text { Error (\%) in COP with reference } \\
\text { to Qureshi and Zubair [9] }\end{array}$} \\
\hline & $\begin{array}{l}\text { Qureshi and } \\
\text { Zubair [9] }\end{array}$ & $\begin{array}{c}\text { Current } \\
\text { model }\end{array}$ & $\begin{array}{c}\text { Qureshi and } \\
\text { Zubair [9] }\end{array}$ & $\begin{array}{c}\text { Current } \\
\text { model }\end{array}$ & $\begin{array}{c}\text { Qureshi and } \\
\text { Zubair [9] }\end{array}$ & $\begin{array}{c}\text { Current } \\
\text { model }\end{array}$ & \\
\hline 0 & 0 & 0 & 0 & 0 & 0 & 0 & 0 \\
\hline 10 & -0.901 & -0.907 & 0.731 & 0.714 & -1.620 & -1.609 & -0.67 \\
\hline 20 & -2.065 & -2.070 & 1.665 & 1.650 & -3.669 & -3.659 & -0.27 \\
\hline 30 & -3.611 & -3.611 & 2.880 & 2.873 & -6.309 & -6.303 & -0.09 \\
\hline 40 & -5.725 & -5.748 & 4.479 & 4.447 & -9.782 & -9.761 & -0.21 \\
\hline 50 & -8.761 & -8.767 & 6.710 & 6.690 & -14.499 & -14.49 & -0.06 \\
\hline
\end{tabular}

TABLE 4: Values of inputs at design point.

\begin{tabular}{lc}
\hline Parameters & Values \\
\hline Evaporator coolant inlet temperature $\left(T_{\text {in,evap }}=T_{7}\right.$ in & 273 \\
K) & \\
Condenser coolant inlet temperature $\left(T_{\text {in, cond }}=T_{9}\right.$ in & $308-313$ \\
$\mathrm{~K})$ & 100 \\
Rate of heat absorbed by evaporator $\left(Q_{\text {evap }}\right.$ in $\left.\mathrm{kW}\right)$ & \\
Product of condenser effectiveness and capacitance & 9.39 \\
rate of external fluid $\left[\left(\epsilon C_{\text {min }}\right)_{\text {cond }}, \mathrm{kW} / \mathrm{K}\right]$ & \\
Product of evaporator effectiveness and capacitance & 8.2 \\
rate of external fluid $\left[\left(\epsilon C_{\text {min }}\right)_{\text {evap }}, \mathrm{kW} / \mathrm{K}\right]$ & 0.65 \\
Isentropic efficiency of compressor $\left(\eta_{\mathrm{cp}, \text { isn }}\right)$ & 0.80 \\
Effectiveness $(\epsilon)$ & $\mathrm{R} 134 \mathrm{a}$, \\
& $\begin{array}{c}\mathrm{R} 1234 \mathrm{yf}, \\
\text { Refrigerants }\end{array}$ \\
& $\mathrm{R} 1234 \mathrm{ze}$ \\
\hline
\end{tabular}

3.1. Input Conditions. The value given in Table 4 has been referred to from Qureshi and Zubair [9] and Khan and Zubair [14] for computation of results in current work.

\subsection{Effect of Condenser Fouling on Compressor Power, Cooling} Capacity, and COP. Figures 4, 5, and 6 represent the effect of condenser fouling with variation on condenser coolant temperature for the refrigerants R134a, R1234yf, and R1234ze, respectively. It is observed that with increase in condenser fouling COP decreases because cooling capacity decreases and compressor work goes on increasing.

Tables 5 and 6 show the comparison of result of percentage of change in compressor power, COP, and cooling capacity with condenser fouling at condenser inlet temperature values of $40^{\circ} \mathrm{C}$ and $35^{\circ} \mathrm{C}$ for the above mentioned refrigerants.

From Tables 5 and 6 , it is observed that the refrigerant R1234yf shows maximum increase in value of change in compressor power $(\%)$ at $T_{\text {in,cond }}=35^{\circ} \mathrm{C}$ and maximum decrease in values of change in COP (\%) and change in cooling capacity (\%) at $T_{\text {in, cond }}=40^{\circ} \mathrm{C}$.

3.3. Effect of Condenser Fouling on Second-Law Efficiency. The comparisons of the results of second-law efficiency at condenser inlet temperature of $40^{\circ} \mathrm{C}, 37.5^{\circ} \mathrm{C}$, and $35^{\circ} \mathrm{C}$

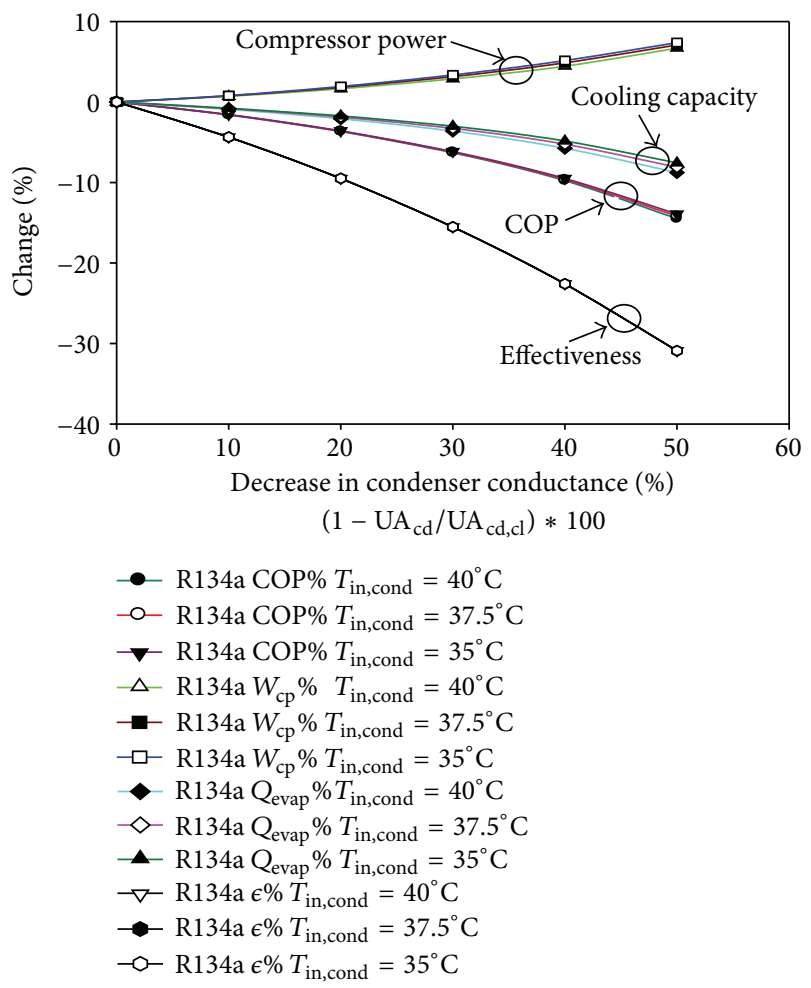

Figure 4: Percentage of change in cooling capacity, compressor power, COP, and effectiveness with decrease in condenser conductance for R134a.

for unfouled condition and 50\% reduction in condenser conductance due to fouling are shown in Table 7.

From the values given in Table 7 , it is clear that the second-law efficiency decreases both under fouled conditions of condenser and for increase in condenser coolant inlet temperature. Among the three refrigerants considered, R1234ze has the highest second-law efficiency whereas R1234yf has the lowest value.

The above results have been calculated for the rated working conditions only. However, under part load conditions cooling capacity $\left(Q_{\text {evap }}\right)$ decreases; hence the load on the condenser reduces. Therefore, with fouling and reduced load on condenser, the reduction in COP and second-law 


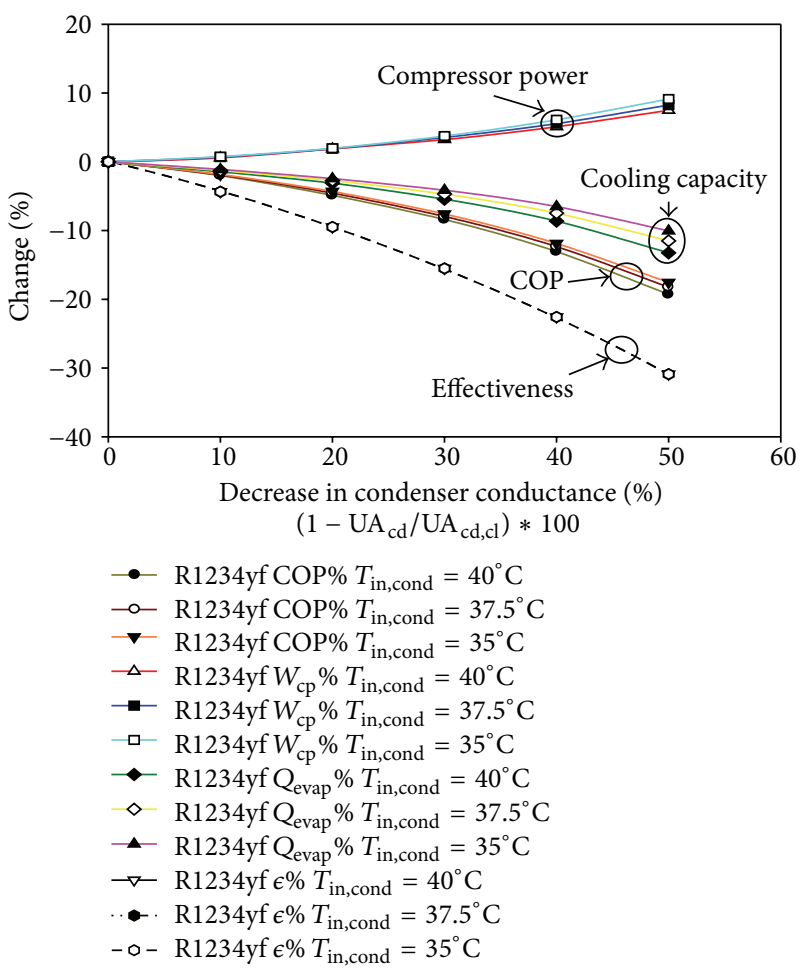

Figure 5: Percentage of change in cooling capacity, compressor power, COP, and effectiveness with decrease in condenser conductance for R1234yf.

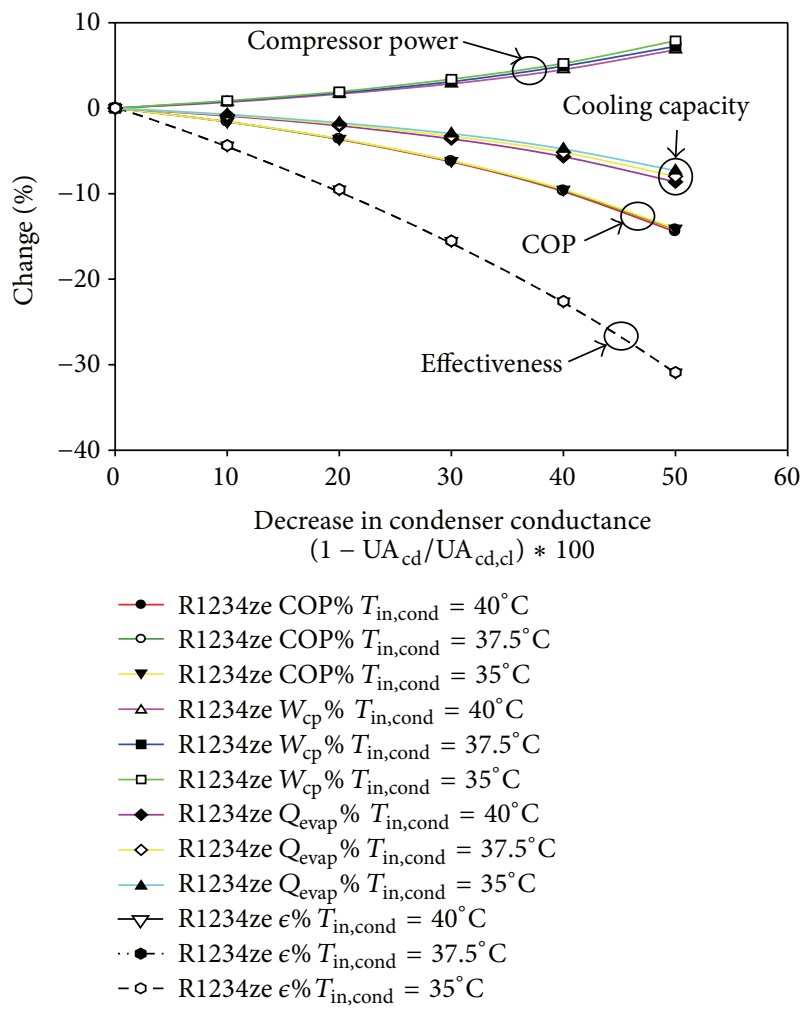

FIgURE 6: Percentage of change in cooling capacity, compressor power, COP, and effectiveness with decrease in condenser conductance for R1234ze.
TABLE 5: Comparison of results for R1234yf and R1234ze with R134a at $T_{\text {in, cond }}=40^{\circ} \mathrm{C}$.

\begin{tabular}{lcccc}
\hline \multirow{2}{*}{ Refrigerant } & $\begin{array}{c}\text { Change in } \\
\mathrm{UA}_{\text {cond }}(\%)\end{array}$ & $\begin{array}{c}\text { Change in } \\
W_{\mathrm{cp}}(\%)\end{array}$ & $\begin{array}{c}\text { Change in } \\
\text { COP }(\%)\end{array}$ & $\begin{array}{c}\text { Change in } \\
Q_{\text {evap }}(\%)\end{array}$ \\
\hline \multirow{2}{*}{ R1234yf } & 10 & 0.57 & -2.01 & -1.46 \\
& 50 & 7.48 & -19.29 & -13.25 \\
\hline \multirow{2}{*}{ R1234ze } & 10 & 0.70 & -1.59 & -0.91 \\
& 50 & 6.83 & -14.47 & -8.63 \\
\hline \multirow{2}{*}{ R134a } & 10 & 0.71 & -1.61 & -0.91 \\
& 50 & 6.69 & -14.49 & -8.77 \\
\hline
\end{tabular}

TABLE 6: Comparison of results for R1234yf and R1234ze with R134a at $T_{\text {in,cond }}=35^{\circ} \mathrm{C}$.

\begin{tabular}{lcccc}
\hline \multirow{2}{*}{ Refrigerant } & $\begin{array}{c}\text { Change in } \\
\mathrm{UA}_{\text {cond }}(\%)\end{array}$ & $\begin{array}{c}\text { Change in } \\
W_{\mathrm{cp}}(\%)\end{array}$ & $\begin{array}{c}\text { Change in } \\
\text { COP }(\%)\end{array}$ & $\begin{array}{c}\text { Change in } \\
Q_{\text {evap }}(\%)\end{array}$ \\
\hline \multirow{2}{*}{ R1234yf } & 10 & 0.74 & -1.85 & -1.12 \\
& 50 & 9.12 & -17.55 & -10.06 \\
\hline \multirow{2}{*}{ R1234ze } & 10 & 0.87 & -1.59 & -0.73 \\
& 50 & 7.41 & -13.88 & -7.50 \\
\hline \multirow{2}{*}{ R134a } & 10 & 0.79 & -1.56 & -0.77 \\
& 50 & 7.38 & -13.91 & -7.56 \\
\hline
\end{tabular}

TABLE 7: Comparison of second-law efficiency (condenser under fouled condition) for refrigerants R1234yf and R1234ze with R134a.

\begin{tabular}{lcccc}
\hline \multirow{2}{*}{ Refrigerant } & $\begin{array}{c}\text { Change in } \\
\mathrm{UA}_{\text {cond }}(\%)\end{array}$ & $\begin{array}{c}\eta_{\mathrm{II}}(\%) \\
T_{\text {in,cond }} \\
40^{\circ} \mathrm{C}\end{array}$ & $\begin{array}{c}\eta_{\mathrm{II}}(\%) \\
T_{\text {in,cond }}=\end{array}$ & $\begin{array}{c}\eta_{\mathrm{II}}(\%) \\
T_{\text {in,cond }} \\
35^{\circ} \mathrm{C}\end{array}$ \\
\hline \multirow{2}{*}{ R1234ze } & 0 & 24.52 & 24.83 & 25.01 \\
& 50 & 20.97 & 21.31 & 21.49 \\
\hline \multirow{2}{*}{ R1234yf } & 0 & 19.60 & 20.53 & 21.23 \\
& 50 & 15.82 & 16.78 & 17.50 \\
\hline \multirow{2}{*}{ R134a } & 0 & 24.37 & 24.69 & 24.88 \\
& 50 & 20.84 & 21.19 & 21.41 \\
\hline
\end{tabular}

efficiency will be less in comparison to the case when the system is operating under full-load conditions. This happens because the increase in condenser temperature will not be as much as when the condenser was operating under full-load conditions.

\section{Conclusions}

On the basis of results obtained from thermodynamic model, the following conclusions are drawn.

In the present work, effect of condenser fouling on the performance of a simple vapour compression cycle has been evaluated by varying condenser conductance, that is, increasing the condenser fouling from 0 to $50 \%$, and also by varying condenser coolant inlet temperature $\left(T_{\text {in,cond }}\right)$ from $35^{\circ} \mathrm{C}$ to $40^{\circ} \mathrm{C}$ for the refrigerants R134a, R1234yf, and R1234ze. It is observed that, under above-mentioned conditions, the maximum percentage increase of compressor power, the 
maximum percentage decrease of cooling capacity, and the maximum percentage decrease in value of COP occur for R1234yf when condenser conductance is assumed to reduce by $50 \%$ followed by R134a and R1234ze. The changes in the above-mentioned parameters are found to be severest for R1234yf.

Further, it is also observed that changes in these parameters are nearly the same for R134a and R1234ze. Thus, on the basis of results obtained, it is evident that R1234ze is a better alternative for R134a.

\section{Nomenclature}

\begin{tabular}{|c|c|}
\hline CFCs: & Chlorofluorocarbons \\
\hline COP: & Actual coefficient of performance \\
\hline $\mathrm{COP}_{\text {rev }}:$ & $\begin{array}{l}\text { Maximum possible coefficient of } \\
\text { performance }\end{array}$ \\
\hline EOS: & Equation of state \\
\hline GWP: & Global warming potential \\
\hline HCFCs: & Hydrochlorofluorocarbons \\
\hline HFO: & Hydrofluoroolefin \\
\hline LGWP: & Low global warming potential \\
\hline ODP: & Ozone depletion potential \\
\hline VCRC: & Vapour compression refrigeration cycle \\
\hline VCRS: & Vapour compression refrigeration system \\
\hline mod: & Model \\
\hline$Q_{\text {cond }}$ and & Rate of heat transfer from the condenser \\
\hline Qevap: & Heat loss in condenser and evaporator \\
\hline$Q_{\text {loss,evap }}:$ & $(\mathrm{kW})$ \\
\hline$W_{\mathrm{cp}}:$ & Power requirement of compressor $(\mathrm{kW})$ \\
\hline$\epsilon, \epsilon_{\text {evap}}$, and & Heat exchanger effectiveness and \\
\hline$\epsilon_{\text {cond }}:$ & effectiveness of evaporator and condenser \\
\hline$C_{\min }:$ & $\begin{array}{l}\text { Minimum value of the thermal } \\
\text { capacitance rate }(\mathrm{kW} / \mathrm{K})\end{array}$ \\
\hline$m_{\text {ref: }}:$ & Refrigerant mass flow rate $(\mathrm{kg} / \mathrm{s})$ \\
\hline$Q_{\mathrm{cp}}:$ & $\begin{array}{l}\text { Rate of heat transfer from the compressor } \\
\text { to the surroundings }(\mathrm{kW})\end{array}$ \\
\hline$\eta_{\mathrm{I}}, \eta_{\mathrm{II}}:$ & $\begin{array}{l}\text { First-law efficiency and second-law } \\
\text { efficiency }(\%)\end{array}$ \\
\hline$\eta_{\text {th,rev }}:$ & Maximum thermal efficiency (\%) \\
\hline$\eta_{\mathrm{cp}, \mathrm{isn}}:$ & Isentropic efficiency of compressor (\%) \\
\hline UA: & Overall conductance $(\mathrm{kW} / \mathrm{K})$ \\
\hline$T_{1}$ to $T_{10}:$ & Temperature at state points $(\mathrm{K})$ \\
\hline$h_{1}, h_{2}, h_{3}, h_{4}$, & The enthalpies of refrigerant at condenser \\
\hline$h_{5}$, and $h_{6}$ : & $\begin{array}{l}\text { exit, evaporator inlet, evaporator outlet, } \\
\text { compressor inlet, compressor outlet, and } \\
\text { condenser inlet }(\mathrm{KJ} / \mathrm{kg})\end{array}$ \\
\hline$T_{\text {in,evar }}$ & Evaporator coolant inlet temperature $(\mathrm{K})$ \\
\hline$T_{\text {in, cond }}$ : & Condenser coolant inlet temperature (K). \\
\hline
\end{tabular}

\section{References}

[1] J. M. Calm, "The next generation of refrigerants-historical review, considerations, and outlook," International Journal of Refrigeration, vol. 31, no. 7, pp. 1123-1133, 2008.

[2] K. M. Karber, O. Abdelaziz, and E. A. Vineyard, "Experimental performance of R-1234yf and R1234ze as drop in replacements for R134a in domestic refrigerator," in Proceedings of the International Refrigeration and Air Conditioning Conference, Paper no. 1228, Purdue University, West Lafayette, Ind, USA, 2012.

[3] N. A. Ansari, B. Yadav, and J. Kumar, "Theoretical exergy analysis of HFO1234yf and HFO1234ze as an alternative replacement of HFC134a in simple vapour compression refrigeration system," International Journal of Scientific and Engineering Research, vol. 4, no. 8, pp. 2229-5518, 2013.

[4] M. O. McLinden, T. Monika, and E. W. Lemmon, "Thermodynamic properties of trans-1,3,3,3-tetrafluoropropene [R1234ze(E)]: measurements of density and vapor pressure and a comprehensive equation of state," in Proceedings of the International Refrigeration and Air Conditioning Conference, Paper no. 2189, Purdue, Ind, USA, 2010.

[5] P. Reasor, V. Aute, and R. Radermacher, "Refrigerant R1234yf performance comparison investigation," in Proceedings of the International Refrigeration and Air Conditioning Conference at Purdue, Paper No. 1085, West Lafayette, Ind, USA, July 2010.

[6] S. Jarall, "Study of refrigeration system with HFO-1234yf as a working fluid: etude sur un système frigorifique utilisant le HFO-1234yf comme fluide actif," International Journal of Refrigeration, vol. 35, no. 6, pp. 1668-1677, 2012.

[7] N. Yamada, M. N. A. Mohamad, and T. T. Kien, "Study on thermal efficiency of low- to medium-temperature organic Rankine cycles using HFO-1234yf," Renewable Energy, vol. 41, pp. 368-375, 2012.

[8] Y. Lee and D. Jung, "A brief performance comparison of R1234yf and R134a in a bench tester for automobile applications," Applied Thermal Engineering, vol. 35, no. 1, pp. 240-242, 2012.

[9] B. A. Qureshi and S. M. Zubair, "Performance degradation of a vapor compression refrigeration system under fouled conditions," International Journal of Refrigeration, vol. 34, no. 4, pp. 1016-1027, 2011.

[10] B. A. Qureshi and S. M. Zubair, "The impact of fouling on performance of a vapor compression refrigeration system with integrated mechanical sub-cooling system," Applied Energy, vol. 92, pp. 750-762, 2012.

[11] B. A. Qureshi and S. M. Zubair, "The impact of fouling on the condenser of a vapor compression refrigeration system: an experimental observation," International Journal of Refrigeration, vol. 38, no. 1, pp. 260-266, 2014.

[12] F. P. Incropera, D. P. DeWitt, T. Bergman, and A. Lavine, Fundamentals of Heat and Mass Transfer, John Wiley \& Sons, 6th edition, 2006.

[13] W. F. Stoecker and J. W. Jones, Refrigeration and Air Conditioning, McGraw-Hill, New York, NY, USA, 1982.

[14] J.-U. Khan and S. M. Zubair, "Design and performance evaluation of reciprocating refrigeration systems," International Journal of Refrigeration, vol. 22, no. 3, pp. 235-243, 1999.

\section{Conflict of Interests}

The authors declare that there is no conflict of interests regarding the publication of this paper. 

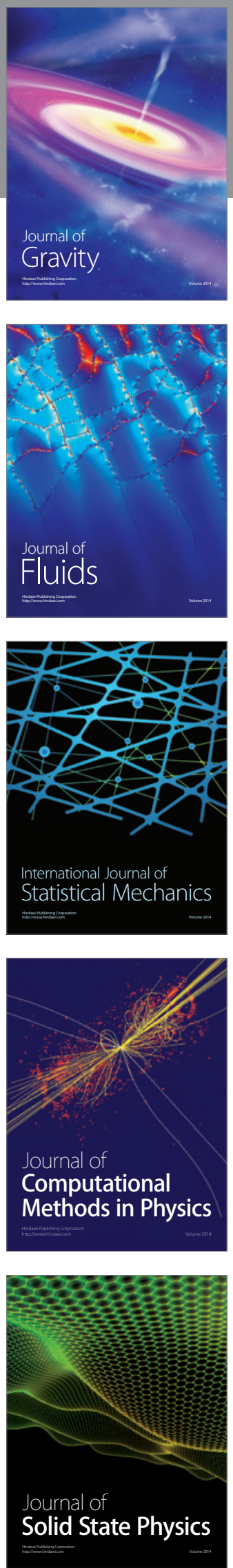

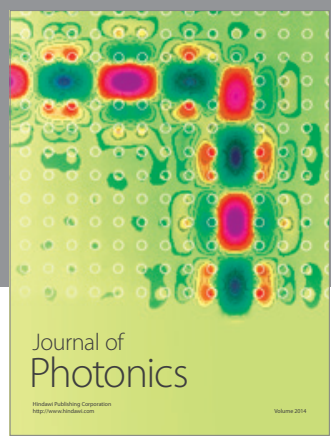

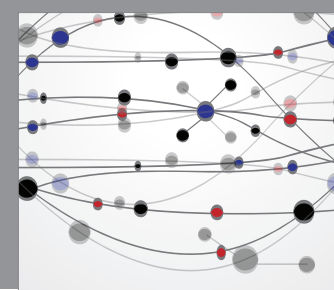

The Scientific World Journal

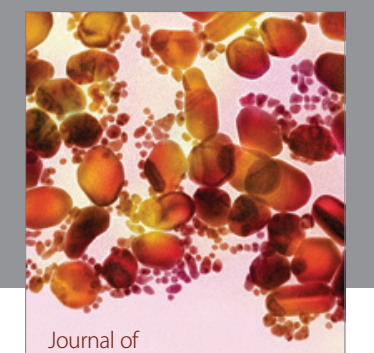

Soft Matter
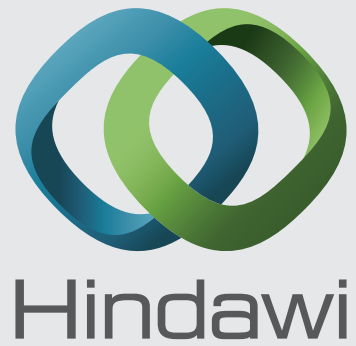

Submit your manuscripts at

http://www.hindawi.com
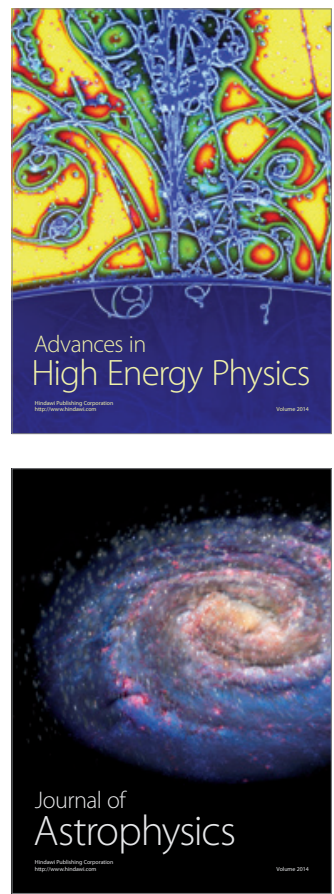
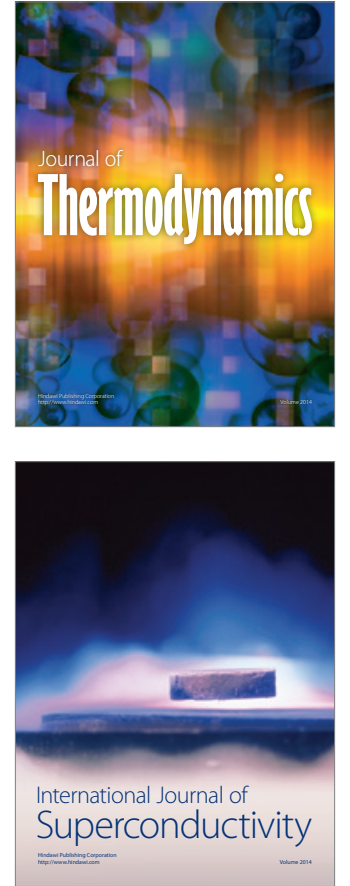
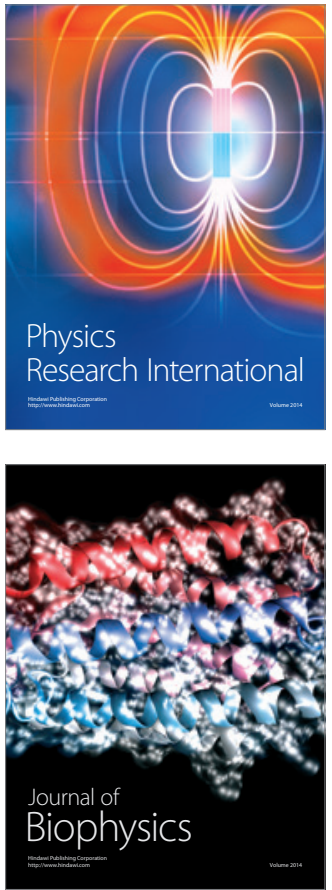
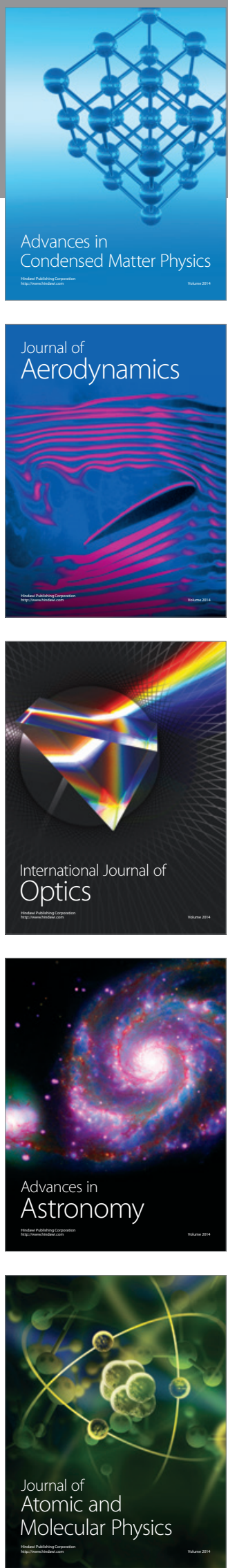